\title{
Foam-forming bacteria in activated sludge effectively reduced by rotifers in laboratory- and real-scale wastewater treatment plant experiments
}

\author{
Agnieszka Pajdak-Stós ${ }^{1}$ - Wioleta Kocerba-Soroka ${ }^{1} \cdot$ Janusz Fyda $^{1} \cdot$ Mateusz Sobczyk $^{1}$. \\ Edyta Fiałkowska ${ }^{1}$
}

Received: 11 October 2016 / Accepted: 20 March 2017 / Published online: 5 April 2017

(C) The Author(s) 2017. This article is published with open access at Springerlink.com

\begin{abstract}
Lecane inermis rotifers were shown to diminish sludge bulking due to their ability to ingest the filamentous bacteria in activated sludge. To determine if rotifers are also able to control branched actinomycetes, we investigated three other Lecane species (Monogononta). In a week-long experiment, only Lecane tenuiseta significantly reduced the density of Microthrix parvicella and Type 0092 filaments, but in a 2-week experiment, actinomycetes were significantly reduced by most of the tested monogonont rotifers: $L$. inermis, Lecane decipiens and Lecane pyriformis. Rotifers $L$. inermis originating from the mass culture were artificially introduced into real-scale wastewater treatment plant (WWTP) in two series. The WWTP was monitored for 1 year. Rotifer inoculation resulted in diminishing of M. parvicella and actinomycete abundance. The experiments showed that different species of rotifers vary in their effectiveness at limiting various types of filamentous organisms. This is the first report demonstrating that one of the most troublesome bacteria, branched actinomycetes, which cause heavy foaming in bioreactors, can be controlled by rotifers. Knowledge of the consumers of filamentous bacteria that inhabit activated sludge could help WWTP operators overcome bulking and foaming through environmentally friendly methods.
\end{abstract}

Keywords Lecane rotifers · Filamentous bacteria ·

Actinomycetes $\cdot$ Sludge bulking $\cdot$ Wastewater treatment plant

Responsible editor: Philippe Garrigues

Agnieszka Pajdak-Stós

agnieszka.pajdak-stos@uj.edu.pl

1 Institute of Environmental Sciences, Jagiellonian University, Gronostajowa 7, 30-387 Kraków, Poland

\section{Introduction}

In most countries with temperate climates, episodes of activated sludge bulking and foaming periodically occur in wastewater treatment plant (WWTP), not only in conventional activated sludge systems but also in membrane bioreactors (MBR) (Cosenza et al. 2013; Di Bella and Torregrossa 2013; Capodici et al. 2015). In properly working activated sludge, various types of filamentous bacteria coexist in amounts that promote the creation of strong flocs and enhance organic matter decomposition (Jenkins et al. 2004). However, when conditions change due to the weather, the type of influent, particular operating conditions or technological problem, the balance can be disrupted, which may result in drastic changes in the amount and proportion of different filamentous bacteria. Their overproliferation leads to activated sludge bulking or foaming or both, and such situation strongly reduces the efficiency of wastewater treatment process. Activated sludge foaming is a common problem worldwide. A foam layer may exceed thickness of $1 \mathrm{~m}$ and may cause impairment of foam removal system, worsening of effluent quality, possible dispersal of pathogens in windblown foam and other extreme difficulties in process control (De los Reys III 2010; Pal et al. 2014). Lately yet, another problem caused by high fraction of filamentous and branched bacteria in the activated sludge arose: foaming in anaerobic digesters (Alfaro et al. 2014; Kougias et al. 2014; Subramanian and Pagilla 2015). The occurrence of foaming caused by filamentous bacteria is usually dependent on temperature, and excessive growth of the most troublesome bacteria, Microthrix parvicella, is often linked to a decrease in temperature below $15{ }^{\circ} \mathrm{C}$, whereas the growth of foam-forming actinomycetes is usually favoured by temperatures over $15^{\circ} \mathrm{C}$ (Eikelboom 2000). However, in a review, Soddel and Seviour (1995) presented conflicting reports about the 
temperature at which foaming occurs. There were discrepancies between optimal temperatures for nocardioform growth observed in wastewater treatment plants and in pure cultures. Such results suggest that temperature dependence of overproliferation of certain types is not a simple causeand-effect relation.

Even though there are methods to overcome bulking and foaming, none is free of constraints. One of the proposed solutions is the use of selectors, but this approach is only effective against some types of filamentous bacteria (Jenkins et al. 2004). Currently, plant operators focus on chemical methods, such as the application of metal salts of aluminium or iron or chlorination (Wanner 1994; Jenkins et al. 2004; Pal et al. 2014). As physical and especially chemical methods have their limitation due to evolving resistance of bacteria, also biological methods were recently proposed. One of them is based on the use of specific bacteriophage infecting foam-forming bacteria (Withey et al. 2005; Petrovski et al. 2011; Pal et al. 2014; Liu et al. 2015; Dyson et al. 2016). The other promising biological alternative is application of rotifers that feed on filamentous bacteria. The rotifer Lecane inermis has been shown to significantly reduce the abundance of different types of filamentous bacteria: M. parvicella (Fiałkowska and Pajdak-Stós 2008), Nostocoida limicola (Pajdak-Stós and Fiałkowska 2012), Type $021 N$ (Kocerba-Soroka et al. 2013a), Type 0092 (Drzewicki et al. 2015), Thiotrix sp. (Kowalska et al. 2014) and Haliscomenobacter (Kowalska et al. 2016).

These results indicate that $L$. inermis rotifer may be considered as a universal filaments consumer, yet so far there were no data about rotifer effectiveness in controlling the branched forms such as actinomycetes producing heavy foaming. Previous direct microscopic observations indicated that actinomycetes were less accessible for $L$. inermis than M. parvicella, but no rigorous experiments have been performed to assess the rotifer capability for reducing the actinomycete colonies (Fiałkowska and Pajdak-Stós 2008).

L. inermis appears to be a very promising alternative to chemical and physical methods to prevent activated sludge bulking, but this species of rotifer ceases to proliferate at temperatures below $8{ }^{\circ} \mathrm{C}$. The minimum temperature at which L. inermis can sustain a positive growth rate is $8^{\circ} \mathrm{C}$, but this has only been observed in one of the four clones of this species (Fiałkowska et al. 2011). The optimal temperature at which this rotifer has exhibited its highest growth rate is $30{ }^{\circ} \mathrm{C}$ (Walczyńska et al. 2016), so at lower temperatures, they require relatively old sludge to reach the density at which they can limit the overproliferation of filaments. Additionally, our previous research showed that an initial $L$. inermis density of $100 \mathrm{ind} / \mathrm{mL}$ resulted in bulking control (Fiałkowska and Pajdak-Stós 2008). The use of this species in treatment plants relies on introducing the rotifers during a warm season, when they have a good chance of proliferating and quickly reducing the number of filamentous bacteria and thus preventing overproliferation in cold seasons. Only under favourable conditions can they maintain filament density at a proper level (1 or 2 on the Eikelboom scale). However, although rotifers are common constituents of activated sludge communities and can significantly improve the properties of activated sludge by enhancing flocculation, the reduction of suspended solids and excessive sludge, conditions that favour rotifer growth in WWTPs, is poorly recognized. As species differ in their reaction to different environmental factors, it seems reasonable to maintain high rotifer biodiversity in WWTPs and consequently ensure higher resilience of the whole community. Therefore, we must identify other rotifers that are effective in the control of filamentous microorganisms, which was the goal of this work. Through two separate experiments, we investigated the ability of three species of Monogononta rotifers, Lecane tenuiseta (Harring, 1914), Lecane decipiens (Murray, 1913) and Lecane pyriformis (Daday, 1905) to reduce the abundance of $M$. parvicella and Type 0092 and the ability of four monogononts, L. inermis (Bryce, 1892), L. tenuiseta, L. decipiens and L. pyriformis, to limit M. parvicella, Sphaerotilus natans and branched actinomycetes.

\section{Materials and methods}

\section{Laboratory-scale experiments}

\section{First experiment}

The activated sludge used for this experiment originated from a municipal wastewater treatment plant, coded as Che, located in eastern Poland. The plant eliminates phosphorus and nitrogen and purifies municipal sewage from the single city (about 65,000 inhabitants). At the time of sampling, the filament index was 3.5, according to the Eikelboom scale, with clear dominance of $M$. parvicella (filament index $(\mathrm{FI})=2.0$ ) and Type 0092 as the second most abundant filament $(\mathrm{FI}=0.8)$. The experiment was carried out on tissue culture plates (TPP) kept in darkness at $20^{\circ} \mathrm{C}$. Eight replicates were performed for each species of rotifer, and eight wells without rotifers served as controls. In this first experiment, clones of L. tenuiseta, $L$. decipiens and $L$. pyriformis were used, and each clone had been obtained earlier from different samples of activated sludge and maintained under laboratory conditions. At the start of the experiment, 100 individuals of each rotifer species were transferred separately to treatment wells, and during this process, approximately $600 \mu \mathrm{L}$ of culture medium (Żywiec brand spring water) was also transferred. The same volume of spring water was added to each control well, and afterwards, $1 \mathrm{~mL}$ of thoroughly mixed activated sludge was added to each well. After 1 week, three $10-\mu \mathrm{L}$ samples were taken from each treatment well, and the rotifers were counted. Their density in $1 \mathrm{~mL}$ of solution and average population growth rate $(r)$ were 
calculated according to formula $r=\left(\ln \left(n_{\mathrm{t}}\right)-\ln \left(n_{0}\right)\right) / t$, where " $t$ " is the day of experiment, " $n$ " is the number of rotifers at the end of the experiment and " $n_{0}$ " is the initial number of rotifers. In addition to these species, solitary native rotifers, such as L. inermis, Cephalodella and different bdelloid species, were observed, but they were excluded from further analysis as they were present in both the treatment and control wells.

To compare the density of filaments in the treatment and control groups, the density factor of the filamentous bacteria, as described by Kocerba-Soroka et al. (2013a), was analysed. Two $30-\mu \mathrm{L}$ subsamples were taken from each well, and $22 \times 22-\mathrm{mm}$ smears were prepared on microscopic slides. The smears were then Gram stained, and digital images of ten randomly chosen fields of view were taken using a Nikon Eclipse 80i microscope with a total magnification of $\times 1000$. The number of filaments crossing the $85 \times 64-\mu \mathrm{m}$ borders was counted in each image.

\section{Second experiment}

The second experiment was carried out on activated sludge collected from a small municipal plant, coded as Zel, located near Kraków (south-eastern Poland). The plant purifies sewage from a single village ( $<1000$ inhabitants). The filament index of this sludge was FI $=3.5$ with obvious dominance of actinomycetes, and the other filaments observed in the sludge were M. parvicella and S. natans. The experiment was also carried out on 24-well tissue culture plates (TPP) with eight replicates for each rotifer species and eight control wells. In this experiment, we used four species of Lecane rotifers: $L$. inermis, $L$. tenuiseta, $L$. decipiens and $L$. pyriformis, and all of the rotifer clones were cultivated in high-density cultures in the lab. As the rotifers differ in size and growth rate, in this experiment, we decided to transfer $100 \mu \mathrm{L}$ of well-mixed culture of each clone to wells containing $1 \mathrm{~mL}$ of activated sludge with eight replicates for each rotifer species, and $100 \mu \mathrm{L}$ of Żywiec brand spring water was added to the control wells. Simultaneously, three $100-\mu \mathrm{L}$ subsamples of original culture were taken and fixed with acidic Lugol solution. Then, all of the individual rotifers were counted, and their initial density per $1 \mathrm{~mL}$ was calculated for each species. The culture plates were incubated for 2 weeks in darkness at a constant temperature of $20^{\circ} \mathrm{C}$.

After 1 week and then after 2 weeks, all of the study rotifers were counted, and their population growth rate $(r)$ was calculated according to the formula given earlier. To calculate the density factor of the filaments, we modified the methodology described earlier because the morphology of the actinomycetes differs from that of M. parvicella or Type 0092 . Actinomycete filaments are tiny and branched and occur in characteristic colonies, so to obtain comparable results to those of M. parvicella or Type 0092, we prepared two smears of 30- $\mu \mathrm{L}$ samples from each treatment and control well and Gram stained them. Each smear was $22 \times 22 \mathrm{~mm}$ in size, and a Nikon Eclipse 80i microscope with a total magnification of $\times 1000$ was used to count the number of colonies. On each smear, we analysed one randomly chosen band within a $1.826-\mathrm{mm}^{2}$ area between the edges of the smear, on which we counted all actinomycete colonies. Thus, two bands were analysed for each treatment well. For the statistical analysis, the average value from two bands per well was calculated. The density of the remaining filaments (including $M$. parvicella and $S$. natans) was also estimated; for the same bands, the filaments crossing their borders were counted.

Analysis of variance (ANOVA with contrasts) was used to detect significant differences in the density of filamentous bacteria between the control and experimental treatments, in which the bacteria remained under pressure from different species of rotifers. Data were transformed (natural logarithm) if they did not meet the assumptions for an ANOVA. The statistical analysis was performed with Statistica 10 (StatSoft Inc. 2011).

\section{Experiment in real-scale WWTP}

In a frame of the project "Integrative system of activated sludge bulking control in wastewater treatment plants", we inoculated activated sludge in different WWTPs with mass-cultured L. inermis. Only one of ten monitored WWTP's suffers regularly from heavy foaming caused by overproliferation of actinomycetes.

WWTP coded as Zel is a small, conventional, domestic plant without $\mathrm{N}$ and $\mathrm{P}$ removal system. The volume of aeration tank is $84 \mathrm{~m}^{3}$, and the volume of secondary clarifier is $20 \mathrm{~m}^{3}$. The WWTP was monitored from December 2014 for over 1 year. Microscopic analyses according to the Eikelboom method (Eikelboom 2000) were performed at 2-week intervals. In this method, the abundance of filamentous organisms observed in a sample is assessed on the base of the reference images included in the method's manual (Eikelboom) and expressed as degrees on a 0 to 5 scale called the FI. The sum of partial indexes assigned to certain type of bacteria has to be equal to total FI. The densities of proto- and metazoans are expressed as degrees on a scale from 0 to 3 where 0 means none and 3 means numerous cells/colonies per slide. We introduced half-point intervals to the previous scales to attain greater precision.

Mass culture of rotifers $L$. inermis was maintained according to the method described by patent application (Pajdak-Stós et al. 2016b). Generally, the rotifers are kept in plastic vessels in Żywiec brand spring water and feed with the nutrition powder (patent no. EP2993978). In such conditions, they reached abundance about 8000 individuals $/ \mathrm{mL}$. Once a week, the rotifers were harvested and in plastic tanks transported to WWTP. 
Rotifers were inoculated directly to aeration tank. The dates, physical parameters of activated sludge and data on rotifer culture volume are given in Table 1.

Rotifer abundance and the two foam-forming bacteria: M. parvicella and actinomycetes were monitored for 1 year.

\section{Results}

\section{Laboratory-scale experiments}

Our first experiment showed that only L. tenuiseta can significantly reduce the density of filamentous bacteria, such as M. parvicella and Type 0092, and compared to the control, the reduction was statistically significant (ANOVA with contrasts, $p=0.012$ ). The density of filaments in the treatments with $L$. decipiens and $L$. pyriformis decreased (Fig. 1), but the differences were not significant. Additionally, the number of rotifers increased during the experiment (Fig. 2), and the increase was most pronounced in L. decipiens and L. pyriformis. The number of the former increased 3.5 times and that of the latter more than 2 times. L. tenuiseta also increased in number but at lower rate. Nevertheless, L. tenuiseta at a relatively low density significantly reduced the densities of both types of filamentous bacteria.

The second experiment indicated that actinomycetes can be significantly reduced by most of the tested rotifer species (ANOVA with contrasts: $L$. inermis, $p=0.001$; L. decipiens, $p=0.0004 ;$ L pyriformis, $p=0.004)$, but in the case of $L$. tenuiseta, the reduction in the number of actinomycete colonies was noticeable (Fig. 3) but not significant. The densities of the other filaments, M. parvicella and S. natans, were significantly reduced by all of the tested rotifers (ANOVA with contrasts: L. inermis, $p=0.0001 ;$ L. decipiens, $p=0.0004$; L. pyriformis, $p=0.0008 ;$ L. tenuiseta, $p=0.0005$ ) (Fig. 4). After 1 week, the number of $L$. inermis, $L$. decipiens and

Table 1 Time table of rotifer application with parameters measured in aeration tank at the moment of inoculation

\begin{tabular}{lllll}
\hline Date & Temperature $\left({ }^{\circ} \mathrm{C}\right)$ & $\mathrm{pH}$ & $\mathrm{DO}(\mathrm{mg} / \mathrm{L})$ & Volume (L) \\
\hline Series I & & & & \\
04 Feb 2015 & 9.6 & 6.6 & 2.5 & 11 \\
11 Feb 2015 & 9.3 & 6.4 & 5.4 & 25 \\
18 Feb 2015 & 9.1 & 6.5 & 0.5 & 15 \\
25 Feb 2015 & 8.5 & 6.7 & 2.1 & 10 \\
Series II & & & & \\
20 May 2015 & 14.4 & 6.7 & 6.9 & 26 \\
26 May 2015 & 14.3 & 6.4 & 1.3 & 25 \\
03 Jun 2015 & 15.4 & 6.6 & 1.3 & 30
\end{tabular}

Table contains volume of rotifer culture with abundance ca. 8000 individuals $/ \mathrm{mL}$

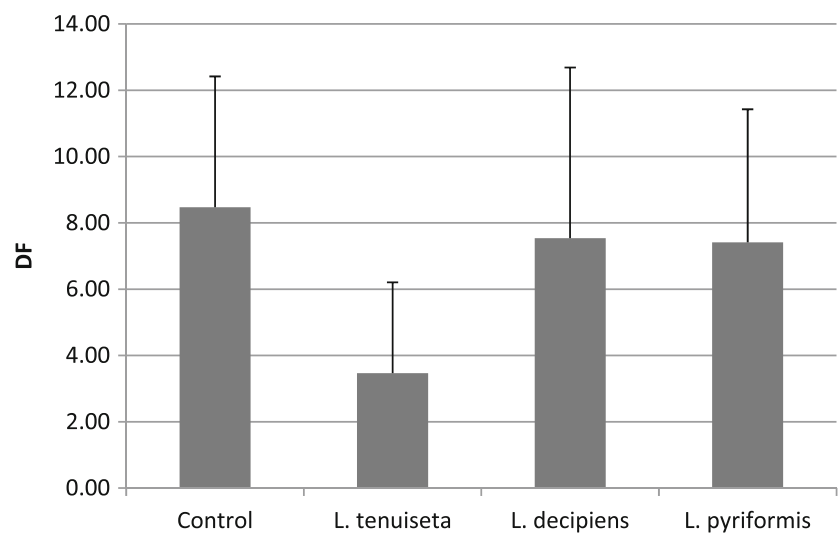

Fig. 1 Mean density factor (DF) values for the M. parvicella and Type 0092 remaining after 1 week under pressure from different rotifers

L. pyriformis increased 4.8, 1.7 and 4.2 times, respectively, whereas $L$. tenuiseta decreased almost 2.5 -fold. After 2 weeks, the density of all of the tested species increased in comparison to the density reached after 1 week. The most abundant was L. inermis, whose density increased almost 25 -fold within 2 weeks (Fig. 5).

\section{Experiment in real-scale WWTP}

The density of rotifers in WWTP and their effect on $M$. parvicella and actinomycete abundance are shown in Fig. 6. Black arrows point the dates of the start of each series of rotifer inoculation. A month since the first series, their index reached value 1 in a 0 to 3 scale. At the same time, actinomycete abundance visibly decreased. Then, after the following 2 months, rotifers were not visible in the subsamples. Rotifer abundance rapidly increased after the second series of inoculation reaching the highest value in a scale and then in October again dropped to 0 (Fig. 6). Dotted arrow indicated the day of sampling when a predatory fungus

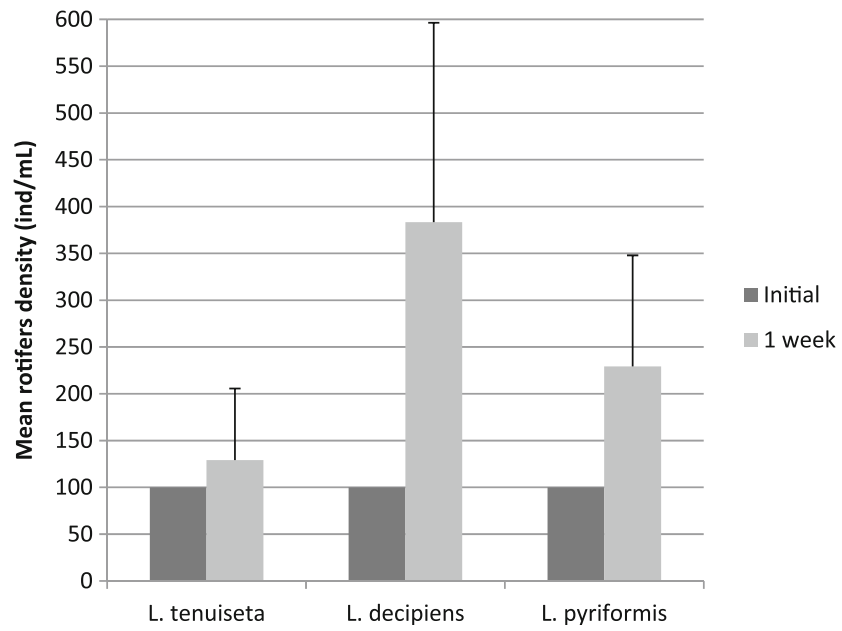

Fig. 2 Mean number of rotifers per millilitre after 1 week of experimentation compared to the initial density of $100 \mathrm{ind} / \mathrm{mL}$ 


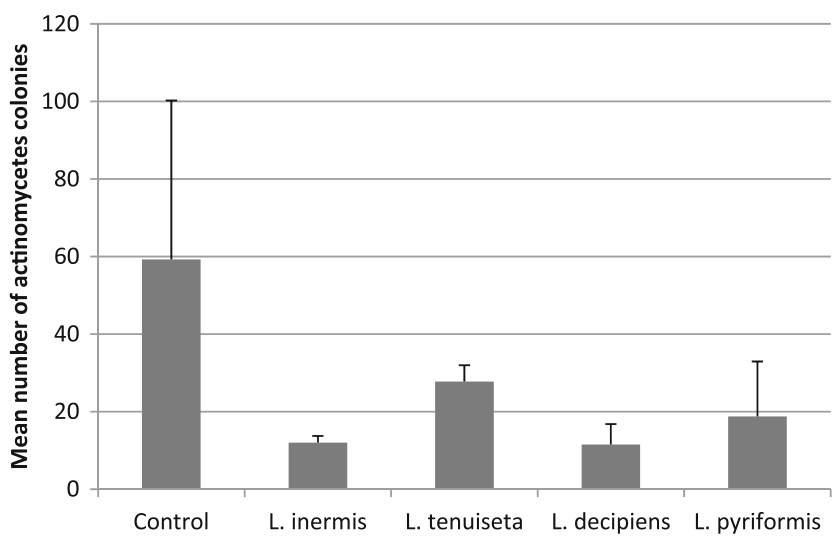

Fig. 3 Mean number of actinomycete colonies remaining after 2 weeks under pressure from different rotifer species compared to the controls

Zoophagus sp. was spotted in the subsamples. In Fig. 6, repeating pattern of relation between rotifer abundance and both foam-forming bacteria density could be noticed.

\section{Discussion}

Our study showed that all of the tested rotifer species are able to significantly reduce filamentous bacteria and/or actinomycete colonies.

\section{Laboratory-scale experiments}

The first experiment showed that $L$. tenuiseta can effectively reduce the abundance of filamentous bacteria, such as M. parvicella and Type 0092, and these results are very promising from the perspective of using this species to prevent activated sludge bulking and as an alternative to $L$. inermis. The morphology of $L$. tenuiseta is very similar to that of $L$. inermis, which is a known consumer of most of the filaments in activated sludge, but $L$. tenuiseta is more adapted to lower temperatures (Fiałkowska et al. 2016). To date, the maximal growth rate reported for L. tenuiseta at $8{ }^{\circ} \mathrm{C}(r=0.16$

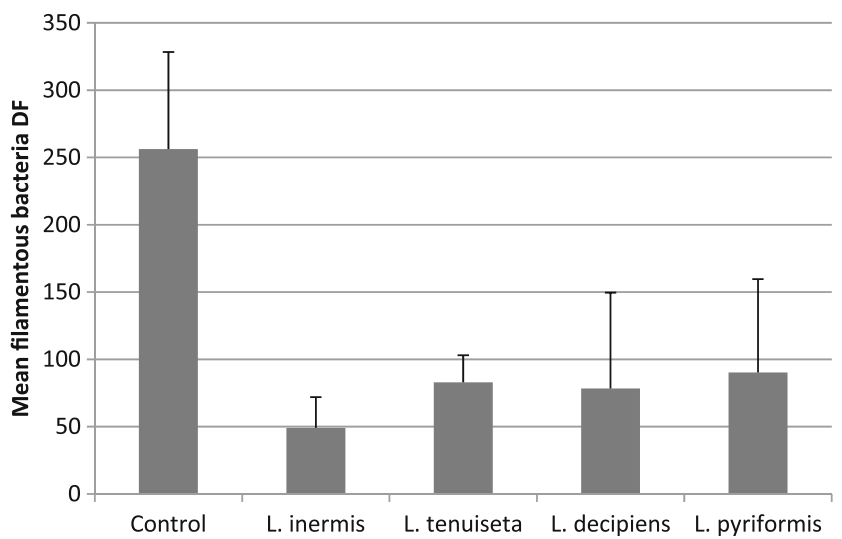

Fig. 4 Mean density factor (DF) values for the M. parvicella and $S$. natans remaining after 2 weeks under pressure from different rotifers

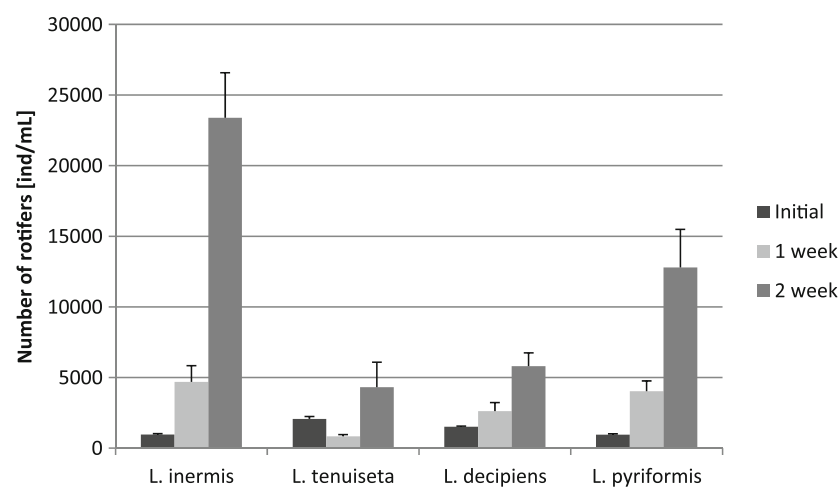

Fig. 5 Changes in the mean number of each rotifer species throughout the 2-week experiment

individuals per day) is much higher than that for $L$. inermis $\left(r=0.03\right.$ day $\left.^{-1}\right)$, but $L$. inermis reaches a higher growth rate at $20{ }^{\circ} \mathrm{C}$. According to previous research (Fiałkowska et al. 2011; Fiałkowska et al. 2016), the growth rate of $L$. inermis can be as high as 0.59 day $^{-1}$, whereas the $L$. tenuiseta " $r$ " can reach a maximum value of between 0.23 and 0.37 day $^{-1}$. The experiments described in this paper were conducted in pure culture under optimal feeding conditions, but the species-specific growth rate could be modified by external conditions, such as resource competition or the presence of harmful substances. In our first experiment with activated sludge, the growth rate of $L$. tenuiseta reached 0.037 day $^{-1}$, and this value was much lower than the maximum growth rate for this species at $20^{\circ} \mathrm{C}$ as well as in comparison with the two other Lecane study species. In the case of $L$. decipiens and L. pyriformis, the $r$ value reached 0.192 and 0.118 day $^{-1}$, respectively. As activated sludge is a mixture of different, often competing species subjected to a combination of typically unknown substances, we could only speculate as to why the growth of $L$. tenuiseta was inhibited. We could not exclude the possibility that $L$. tenuiseta is more vulnerable to toxic substances than the other tested Lecane species. Additionally, $L$. inermis and $L$. tenuiseta are characterized by similar dietary preferences and could potentially inhabit the same niche, but L. tenuiseta proliferates more rapidly at lower temperatures

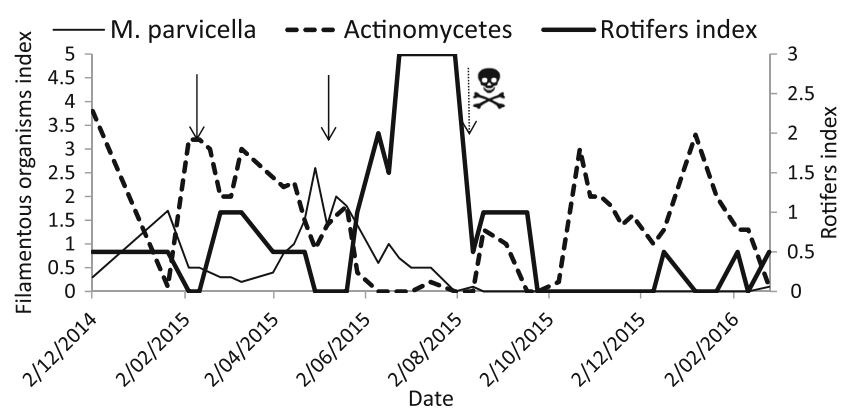

Fig. 6 Indexes of rotifers, actinomycetes and M. parvicella in activated sludge originating from Zel WWTP. Black arrows show the beginning of rotifer inoculation, and dotted arrow with a scull icon shows occurrence of predatory fungus in subsamples 
compared to L. inermis. Different temperature preferences are very advantageous as means for these species to minimize competition for resources, and seasonal temperature fluctuations seem to favour the coexistence of these two species at intermediate temperatures and the dominance of one or the other at extreme temperatures. Edmondson (1946) indicated that temperature and food availability are the most important factors affecting the lifespan, population abundance and growth rate of rotifers, and previous research (Fiałkowska et al. 2016) showed that the growth rate of L. tenuiseta at $20^{\circ}$ $\mathrm{C}$ ranges from 0.10 to 0.41 day $^{-1}$ depending on the clone or linage. Our experiments were conducted at $20 \pm 1^{\circ} \mathrm{C}$, at which the growth rate of L. tenuiseta was the lowest (Fig. 2) compared to the other tested rotifers. Despite this result, L. tenuiseta was, surprisingly, the most effective of the study rotifers at reducing filamentous bacteria in the first experiment. Although the increase in abundance was highest for L. decipiens and L. pyriformis, almost 3.5 and 2 times, respectively, they did not significantly reduce any of the investigated filaments. In the second experiment, on the other hand, these two species were able to reduce $M$. parvicella. The probable reason for this effect is the prolonged exposure of the filamentous bacteria to the rotifers; the second experiment lasted for 2 weeks, during which L. decipiens and L. pyriformis significantly reduced the density of filamentous bacteria. Little information on the biology of these species is available, but these rotifers have a wide tolerance to temperature. L. decipiens occurs within a temperature range from 3 to up to $25{ }^{\circ} \mathrm{C}$ but reaches maximum abundance at approximately $16{ }^{\circ} \mathrm{C}$ (Bērzinš and Pejler 1989). There have been no earlier reports on the occurrence of $L$. decipiens and L. pyriformis in activated sludge.

The results of the second experiment also demonstrated that L. inermis, L. decipiens and L. pyriformis significantly limited the number of actinomycete colonies, and these organisms are troublesome due to their morphology. Although they are usually classified as filamentous organisms, they grow in "bushy" colonies with branched filaments, and during their excessive growth, which usually occurs in warm season, this type of filament creates a dense foam on the activated sludge surface and negatively influences its sedimentation properties. For the first time, our results showed that the density of branched actinomycetes can be significantly reduced by L. inermis, L. decipiens and L. pyriformis (Fig. 3). However, although the mean density of the actinomycete colonies decreased in the presence of L. tenuiseta (Fig. 3), the effect was not significantly different than the control. This filament also seemed to be affected by L. tenuiseta, but the effect was too weak to be significant relative to the highly variable control. There are several possible explanations of this effect. First of all, the activated sludge used in this experiment might be harmful to this rotifer (Fig. 5) due to the presence of toxins in the inflowing sewage, which was indicated by the decreasing number of $L$. tenuiseta after 1 week compared to its initial density. Interestingly, a similar pattern was observed in the first experiment, so we could not exclude that L. tenuiseta is the most vulnerable species. Fortunately, as can be seen in Fig. 5, this species is able to adapt and improve its ability to proliferate. Another explanation could be related to the food preferences of this species; although actinomycetes were dominant in the experimental sludge, there were also plenty of non-branched filamentous bacteria that were significantly reduced by $L$. tenuiseta.

The feeding behaviours of the species used in our experiment have not been examined. However, some information about grazing by rotifers on filaments in activated sludge appeared several years before and only concerned one Lecane species. Therefore, we cannot exclude the possibility that there are some differences in the construction of the feeding apparatus of L. tenuiseta that makes it less effective at feeding on filaments, especially branched ones such as those of the actinomycetes.

\section{Experiment in real-scale WWTP}

Our results evidenced that artificial inoculation of rotifers L. inermis is possible in real-scale WWTP and that higher abundance of rotifers results in effective control of foam-foaming bacteria such as $M$. parvicella and actinomycetes. Although there are reports on negative correlation between rotifers and filament index in real-scale WWTPs (Fiałkowska and Pajdak-Stós 2008), this is the first observation of rotifer impact on branched foam-foaming actinomycetes. In Fig. 6, it is clearly depicted that the second series of rotifer inoculation led, after temporary decline, to rapid proliferation of artificially introduced rotifers in aeration tank. Increasing density of rotifers was followed by the decrease in the density of M. parvicella and actinomycetes. As Fig. 6 shows, the first inoculation was less successful probably due to the temperature too low to ensure high enough rotifer growth rate. This is consistent with our earlier results (Fiałkowska et al. 2011; Pajdak-Stós and Fiałkowska 2012) showing that population growth rate of $L$. inermis at $8{ }^{\circ} \mathrm{C}$ is close to 0 . Temperature in aeration tank during the first series of inoculation varied between 8.5 and $9.5^{\circ} \mathrm{C}$. Rotifer abundance a month later appeared to be high enough to reduce actinomycete index by half within less than 4 weeks (Fig. 6). Second series of inoculation conducted when temperature varied between 14.3 and $15.4^{\circ} \mathrm{C}$ resulted in relatively rapid rotifer proliferation and, in consequence, reduction of $M$. parvicella and actinomycete abundance. The reason why rotifers were not observed in August was probably massive occurrence of predatory fungus Zoophagus sp. earlier reported as a threat to rotifer population in WWTPs (Pajdak-Stós et al. 2016a).

Most importantly, this research found that species other than $L$. inermis are capable of limiting the growth of filamentous bacteria and, especially, branched actinomycetes. This 
knowledge will be used to improve biological methods of bulking control, and a higher biodiversity of artificially introduced rotifers could help to maintain the resilience of the rotifer community in the fluctuating WWTP environment. Using various species of rotifers as natural consumers of filamentous bacteria could be an alternative method to control the most troublesome bacteria and protect treatment plants from bulking throughout the year. Additional advantage of described biological method is that, as it was shown, earlier increasing density of rotifers does not negatively influence physicochemical parameters of effluent (Kocerba-Soroka et al. 2013b). Moreover, rotifers play an important role in floc formation, reduction of excess biomass production and consumption of dispersed bacteria in activated sludge (Lapinski and Tunnacliffe 2003).

Our results show for the first time how effective artificially introduced rotifers could be in controlling M. parvicella and actinomycetes - bacteria causing heavy foaming in WWTPs. The monitoring of rotifer abundance with relation to other process parameters in real-scale WWTP helped to define optimal condition for rotifer inoculation on the one hand and potential limitation of the method on the other.

\section{Conclusions}

Lecane rotifers are able to control abundance of branched actinomycetes, one of the main causes of scum formation in WWTPs. Our research showed that rotifer species: L. inermis, $L$. decipiens, $L$. pyriformis and $L$. tenuiseta are all able to ingest filamentous and branched bacteria and could be used as a promising biological tool for control of activated sludge bulking and foaming. The knowledge gained in the course of experiments, especially in real-scale WWTP, will help WWTP operators to optimize sludge sedimentation properties.

Acknowledgements We thank Dr. J. Ejsmont-Karabin for professional help with rotifer species determination and Dr. Aleksandra Walczyńska and two anonymous reviewers for valuable comments on earlier version of the manuscript. This research was supported by The National Center for Research and Development Grant GEKON1/O3/214361/8/2014 and Jagiellonian University Funds DS/WBiNoS/INoS/757.

Open Access This article is distributed under the terms of the Creative Commons Attribution 4.0 International License (http:// creativecommons.org/licenses/by/4.0/), which permits unrestricted use, distribution, and reproduction in any medium, provided you give appropriate credit to the original author(s) and the source, provide a link to the Creative Commons license, and indicate if changes were made.

\section{References}

Alfaro N, Cano R, Fdz-Polanco F (2014) Effect of thermal hydrolysis and ultrasounds pretreatments on foaming in anaerobic digesters. Bioresour Technol 170:477-482
Bērzinš B, Pejler B (1989) Rotifer occurrence in relation to temperature. Hydrobiologia 175(3):223-231

Capodici M, Di Bella G, Nicosia S, Torregrossa M (2015) Effect of chemical and biological surfactants on activated sludge of MBR system: microscopic analysis and foam test. Bioresour Technol 177:80-86

Cosenza A, Di Bella G, Mannina G, Torregrossa M (2013) The role of EPS in fouling and foaming phenomena for a membrane bioreactor. Bioresour Technol 147:184-192

De-los Reyes FL III Foaming (2010) In: Seviour, R. J., \& Nielsen, P. H. (eds.). (2010). Microbial ecology of activated sludge. IWA publishing

Di Bella G, Torregrossa M (2013) Foaming in membrane bioreactors: identification of the causes. J Environ Manag 128:453-461

Drzewicki A, Kowalska E, Pajdak-Stós A, Fiałkowska E, KocerbaSoroka W, Sobczyk Ł, Fyda J (2015) Experimental attempt at using Lecane inermis rotifers to control filamentous bacteria Eikelboom type 0092 in activated sludge. Water Environ Res 87(3):205-210

Dyson ZA, Tucci J, Seviour RJ, Petrovski S (2016) Isolation and characterization of bacteriophage SPI1, which infects the activated-sludgefoaming bacterium Skermania piniformis. Arch Virol 161(1):149158

Edmondson WT (1946) Factors in the dynamics of rotifer populations. Ecol Monogr 16:357-362

Eikelboom DH (2000) Process control of activated sludge plants by microscopic investigation. IWA publishing, London pp. 85-102

Fiałkowska E, Kocerba W, Pajdak-Stos A, Klimek B, Fyda J (2011) Clonal variation in reproductive response to temperature by a potential bulking control agent, Lecane inermis (Rotifera). Water Sci Technol 64(2):403-408

Fiałkowska E, Pajdak-Stós A (2008) The role of Lecane rotifers in activated sludge bulking control. Water Res 42(10):2483-2490

Fiałkowska E, Pajdak-Stós A, Fyda J, Kocerba-Soroka W, Sobczyk M (2016) Lecane tenuiseta (Rotifera, Monogononta) as a biological tool candidate for bulking prevention in a cold season. Desalination and Water Treatment DOI. doi:10.1080/19443994. 2016.1192565

Jenkins D, Richard MG, Daigger GT (2004) Manual on the causes and control of activated sludge bulking and other solids separation problems. Lewis Publishers

Kocerba-Soroka W, Fiałkowska E, Pajdak-Stós A, Klimek B, Kowalska E, Drzewicki A, Salvado H, Fyda J (2013a) The use of rotifers for limiting filamentous bacteria type $021 \mathrm{~N}$, a bacteria causing activated sludge bulking. Water Sci Technol 67(7):1557-1563

Kocerba-Soroka W, Fiałkowska E, Pajdak-Stós A, Sobczyk M, Pławecka M, Fyda J (2013b) Effect of the rotifer Lecane inermis, a potential sludge bulking control agent, on process parameters in a laboratoryscale SBR system. Wat Sci Tech 68(9):2012-2018

Kougias PG, De Francisci D, Treu L, Campanaro S, Angelidaki I (2014) Microbial analysis in biogas reactors suffering by foaming incidents. Bioresour Technol 167:24-32

Kowalska E, Paturej E, Zielińska M (2014) Use of Lecane rotifers for limiting Thiothrix filamentous bacteria in bulking activated sludge in a dairy wastewater treatment plant. Arch Biol Sci 66(4):13711378

Kowalska E, Paturej E, Zielińska M (2016) Use of Lecane inermis for control of sludge bulking caused by the Haliscomenobacter genus. Desalin Wat Treat 57(26):1-8

Lapinski J, Tunnacliffe A (2003) Reduction of suspended biomassin municipal wastewater using bdelloid rotifers. Water Res 37:2027-2034

Liu M, Gill JJ, Young R, Summer E J (2015) Bacteriophages of wastewater foaming-associated filamentous Gordonia reduce host levels in raw activated sludge. Scientific reports 5

Pal P, Khairnar K, Paunikar WN (2014) Causes and remedies for filamentous foaming in activated sludge treatment plant. Global Nest $\mathrm{J}$ 16(4):762-772 
Petrovski S, Robert J, Seviour RJ, Tillett D (2011) Characterization of the genome of the polyvalent lytic bacteriophage GTE2, which has potential for biocontrol of Gordonia, Rhodococcus, and Nocardiastabilized foams in activated sludge plants. Appl Environ Microbiol 77:3923-3929

Pajdak-Stós A, Fiałkowska E (2012) The influence of temperature on the effectiveness of filamentous bacteria removal from activated sludge by rotifers. Water Env Res 84(8):619-625

Pajdak-Stós A, Ważny R, Fiałkowska E (2016a) Can a predatory fungus (Zoophagus sp.) endanger the rotifer populations in activated sludge? Fungal Ecol 23:75-78

Pajdak-Stós, A., Fiałkowska, E., Fyda, J., Kocerba-Soroka, W., Sobczyk, M. (2016b). (Jagiellonian University) A method of mass culture of Lecane rotifers EP2993978 (A1) European Patent Application.
Soddell JA, Seviour RJ (1995) Relationship between temperature and growth of organisms causing Nocardia foams in activated sludge plants. Water Res 29(6):1555-1558

Subramanian B, Pagilla KR (2015) Mechanisms of foam formation in anaerobic digesters. Colloids and Surfaces B: Biointerfaces 126: $621-630$

Walczyńska A, Kiełbasa A, Sobczyk M (2016) 'Optimal thermal range' in ectotherms: an important concept for understanding the temperature-size rule. J Therm Biol 60:41-48

Wanner, J. (1994). Activated sludge: bulking and foaming control. CRC Press.

Withey S, Cartmell E, Avery LM, Stephenson T (2005) Bacteriophagespotential for application in wastewater treatment processes. Sci Tot Env 339:1-18 